Howe, C., \& Boyer, D. (2015). Aeolian politics. Distinktion: Scandinavian Journal of Social Theory, 16(1). http://doi.org/10.1080/1600910X.2015.1022564

\title{
Aeolian politics
}

\author{
Cymene Howe* and Dominic Boyer \\ Rice University, Anthropology, Houston, Texas, USA \\ *Corresponding author. Email: $\underline{\text { ach1@ rice.edu }}$
}

Our project in this article is to unwind 'wind power' as a consolidated conceptual object and to consider the ventifactual arrangements of its political materiality. In a time when carbon incineration has been exposed as among the greatest ecological threats to humanity and other life on the planet, renewable energy forms, like wind power, are commonly assumed to have a clear, logical, and obvious salvational purpose: a path away from fossilized resources and toward sustainable sources of energy. Mexico has established some of the most far-reaching and comprehensive climate legislation in the world, including mandates for renewable energy production. The Isthmus of Tehuantepec, in the Southern state of Oaxaca, now hosts the densest concentration of on-shore wind development anywhere on the planet. We find, however, that the 'good' of wind is differentially felt. The power of the wind is not singular, but rather as multiple as the world it inhabits. We thus develop an argument against a singular interpretation of "wind power' and toward a surfacing of wind's manifold effects and ways of mattering. We call this domain: aeolian politics. In this article, we take several snapshots of aeolian politics to help articulate its multiplicity, showing how wind power becomes contoured by land and desire and by infrastructure and technological management. We also see aeolian political life entangled with cosmologies and subjectivities and implicated within the ethical domains of sustainable development.

Keywords: energy; Mexico; new materialisms; Oaxaca; politics; sustainability; wind 
In some places, the dust never seems to settle. Throughout Mexico's Isthmus of Tehuantepec wind finds its way everywhere, lifting particulate matter, raising small stones from the road, harassing the matted fur of a dog, insinuating itself against the lopping blades of turbines to make electricity. The wind in the Isthmus, as everywhere, is a negotiation between gases that are compelled across space and time by combinations of heat and cold differentials, floating over land and sea, pressured shifts in directionality and potency. This is the physicality of the wind, its material life. Wind becomes contoured by objects in its path - mountains and hills, cliffs and stands of forest, buildings and creatures. It also willfully exercises its force upon these things, carving, cracking, and pressuring - leaving ventifactual imprints. It draws our attention to points of contact and intraconnective incorporations (Barad 2007) and we often sense it best through touching (in) it (Ingold 2007). We know the wind is there because of what it does. It is a relief from the heat, a force to struggle against, a chilling medium of rain, or a welcome bluster that blows [End Page 31] smoke from our eyes. But the power of the wind is not singular. It is as multiple as the world it inhabits; winds both absorb and form contexts and conditions.

The winds of the Isthmus of Tehuantepec-Mexico's narrowed girth in the southern state of Oaxaca-are legendary. Thanks to the barometric pressure differential between the Gulf of Mexico and the Pacific Ocean, they are among the steadiest and strongest winds to cross land anywhere in the world. They have been a nuisance and a cosmological force to Istmeños for centuries, but in the late twentieth century they began to be viewed as an opportunity for generating electricity and building capital. Facing the twilight of petro-statecraft, Mexico established some of the most far-reaching and comprehensive climate legislation in the world, setting legally binding targets for renewable energy sources to provide $35 \%$ of the nation's electricity by 2024. In the past several years wind parks have proliferated, roads have been laid, and small and large fortunes made. The Isthmus of Tehuantepec now represents the densest concentration of on-shore wind development anywhere in the world. In 2008 there were two parks producing 84.9 megawatts of wind-generated electricity (energía eólica); four years later there were 15 parks producing over 1300 megawatts, a 1467\% increase that has made Mexico the second largest wind power producer in Latin America after Brazil. The wind boom has catalyzed new alliances and conflicts at both local and national levels. The expansion of wind parks has, at times, made neighbors, friends, and families less neighborly, less friendly, or less familial depending on which side of the wind one stands. Those supporting wind power speak of global climatological good and local economic development. Those opposed to wind parks make accusations of economic imperialism by foreign capitalists coming, once again, to colonize the region with their extractive methods. Local landowners who receive usufruct rents, caciques (local bosses), and politicians (who are often accused of taking bribes or embezzling funds) are viewed with suspicion. Questions about indigenous peoples' sovereignty and campesinos' (farmers') rights also loom large. In the Isthmus, the wind is increasingly freighted with politics. It makes little sense to speak of 'wind power' as something other than one particular discursive manifestation of a more complex and turbulent aeolian politics.

Our project in this article is to unwind 'wind power' as a consolidated conceptual object and to consider the ventifactual arrangements of its political materiality. If we are to take seriously the vitality of matter, as Jane Bennett has suggested, then we ought to understand that material contingencies are 'as much wind as thing' and that in 'an effluence' such as wind, we find trajectories that are not necessarily intended (Bennett 2010,119). In a time when carbon incineration has been exposed as among the greatest ecological threats to humanity and other life on the planet, renewable energy forms, like wind power, are commonly assumed to have a clear, 
logical, and obvious salvational purpose: a path away from 'pyromania' (Scheer 2004) and toward 'sustainability'. We are thus invited to embrace and support 'wind power' as an objective force for good. But in our research ${ }^{1}$ we have found that 'wind power' is nowhere singular or objective and, if it is good, it is only for some and not for others. We thus develop an argument against a singular interpretation of 'wind power' and toward a surfacing of its manifold effects and ways of mattering. We call this domain: aeolian politics ${ }^{2}-$ the multiple and contingent political trajectories of the wind, as it is domesticated for electric energy, as it is made a commodity, and as it is taken as a redemptive metaphor for a world in climatological peril.

In this article, we take several snapshots of aeolian politics to help articulate its multiplicity. We show how wind power becomes contoured by land and desire and by [End Page 32] infrastructure and technological management. We also see aeolian political life entangled with cosmologies and subjectivities and implicated within the ethical domains of sustainable development. This mapping of an 'ecology of relationships' (Descola 2013a, 5) does not draw deep divisions between the ontological capacities of nature and society, but instead allows for a careful probing of ontological recompositions (Bogost 2012; Descola 2013a, 2013b; Jasanoff 2010; Massumi 2009). The particular physicality of the wind provides a uniquely mobile space of reflection on the natures of power and purpose, causality and effect. Unlike other so-called 'resources' - such as water, land, or oil - wind evades enclosure; it is nothing if it is not movement, and thus it is a force that is not easily made into a propertied thing. It is elementally loose: a force that can only ever be captured, never contained. ${ }^{3}$ While the force of the wind has long been domesticated by human actors - milling grain, flying kites, blowing ships to the New World - industrial-scale electricity generation and the sprawl of wind parks is unprecedented, both in the Isthmus and in the world. Thus we need to understand how wind is now known differently_ not as it has been for millennia — but as a renewable 'resource,' and as 'green energy.' As wind is increasingly cast as a valuable commodity and as its powers are rapidly industrialized, we are interested in the turbulent political spaces this uncovers. 'Wind power' is now designated as a force with the potential to redraft the energetic relationship between humanity and the environment; it has been made to assume the responsibility of global climatological care. Thus while the wind has always mattered, it has now come to matter in different ways.

In the spirit of this special issue, we draw inspiration from recent social and political theories that highlight the role of materials and materialities in the workings of social life (Barad 2007; Bennett 2010; Braun and Whatmore 2010; Harman 2010; Latour 2004a; 2005; Morton 2013a; Stengers 2010), and we juxtapose these considerations with how Istmeño and Mexican political knowledges and ethical imaginations seek to grasp and shape the elusive force of wind. We look for analytical balance in the critical engagement of an imbalanced world. Our concerns are situated not simply in the plane of academic debate but within the unprecedented global environmental challenges faced by planetary life. Anthropocenic conditions of climate change, species extinction, and ocean acidification prompt us to accent the contemporary and unparalleled restructuring of earth's bio-, litho-, -aqua and atmosphere. Tremendous anthropogenic shifts like global warming, as Timothy Morton has described, constitute 'hyperobjects' in their own right, epistemically disabling us as they place a mirror to human conceits and reflect a conspicuous fragility (Morton 2013b, 2). Air itself, and wind as its animated form, draws our attention to these contemporary moments of 'suspension' (Choy 2011; Choy and Zee 2015) and toward more atmospheric 'attunements' (Stewart 2011). Refigurations between material, human, and non-human worlds also demand that we imagine political 
possibilities beyond material determinisms and social structural theories that underwrote the industrializing logics of the past three centuries. As anthropocentric social theory comes to incorporate material and ontological insights, however, we wish to maintain an oscillating appreciation for the ontological and the phenomenological qualities of 'wind power'. We believe that wind calls for a 'deterrestrializing' of thought in regard to political materials (Howe 2015). Thus, we call attention to a turbulent middle ground here, aiming to deconstruct biopolitical appropriations of wind while also highlighting wind's material powers in ontological terms. Our aeolian political analysis follows the wind and the forms of life through which it passes, pulling back the layers of political multiplicity from wind to land and from grid to green. [End Page 33]

\section{i. Viento, bi, wind}

The north wind whips through, in the streets papers and leaves are chased with resentment.

Houses moan, dogs curl into balls.

There is something in the afternoon's finger, a catfish spine, a rusty nail.

Who can tell me why I meditate on this afternoon?

Why is it birthed in me to knife the heart of whoever uncovered the mouth of the now whipping wind, to jam corncobs in the nose of the ghost that pants outside?

\section{(Víctor Terán, 'The North Wind Whips')}

Victor Terán is a poet and a teacher. One suspects that he would put poet first when describing himself, but he seems equally committed to sharing his words and perspective in the medium of pedagogy. He is also a man wholly opposed to the spread of wind power projects across the Isthmus of Tehuantepec, his native land. Victor's renown as a literary figure and proponent of binnizá (Zapotec) cultural and linguistic preservation preceded his fame as an outspoken critic of the wind parks. The place where we were finally able to meet him one Sunday afternoon evoked none of these political or preservationist qualities. Instead it was an utterly forgettable, but more or less accurately named, restaurant called La Internacional that had the somewhat dubious reputation of attracting Spaniards involved in the wind industry. It was also one of the few places in a very hot town that could boast of air conditioning, an apt climate for our conversation about other kinds of air and wind and breath and everything alive. 
'You know, the wind has many meanings', Victor began. In Zapotec the word is bi. And $b i$ is what designates the air and the breath. 'It is the soul of a person. And it animates everything'. Linguistically, Victor explained, the concept of $b i$ is used to describe and to signal and to name all animate beings. And it is for this reason that nearly all of the binnizá words used to designate an animal or a plant begin with the prefix of bi. Including binnizá (the 'people') itself. He went on. Bini represents a seed, its reproductive essence. And so it is possible to say that bini is the soul, or the seed, of a person, their inherent substance. Bi names the pig that makes the sound bibi and it names the worm, the maggot, that crawls from dead flesh: bicuti is the creature that is both a product of spoiling meat and one that furthers fleshly decomposition. The metaphoric life of language was of interest to Victor, and to us, but his emphasis remained on the inseparability of $b i$ from its essential place in structuring the lexicon. $B i$ is etymologically inherent to expression in the same way that it is fundamental to life. 'Without air there is no life and for this reason we use this prefix, $b i$, for everything. It is very interesting and it is very important because $b i$ is the soul, the air, the breath, and the wind as well; it is a bundle of meanings'. $B i$ is more [End Page 34] than a prefix then, it is a repertoire of sensation and being that shapes the metaphoric life of language and the subjects that utter and inhabit it.

Victor depicts it simply. 'Without the air we would not exist. Without the wind we would not exist'. The first animates, and the second is animated. Cosmologically, there is a trinity of winds in Zapotec: two from the north and the other from the south. The old north wind, el viento viejo should not be mistaken for a feeble wind. It is in fact the opposite: the wind that made the world through its astounding force, its primal intensity. Biyooxho is the northern wind of ancient genealogy that emerged at the beginning of time, 'pushing the world into existence'. A less storied wind, but one that all Istmeños know equally well is biguiaa, the northern wind that is quotidian and less dramatic but still insistent when it blows. And finally, there is the southern wind ( $b i$ niza), the wind of the sea and the water, a revitalizing and gentle wind that soothes the heat. It gathers across the Laguna del Mar Muerto (the dead sea lagoon), southeast of the Laguna Inferior (lower lagoon), just on the edge of the Gulf of Tehuantepec. Bi, the air/life/breath/wind is married to niza (the breeze) and in this union becomes moist. Bi niza is often described as a feminine wind, a more tender sensation, especially when compared to each of the northerly winds, which are inversely described as masculino. In more than a few instances the gusting northern wind, el viento viejo, biyooxho, has been described as 'the devil's wind'. Its heat and intensity make it seem as though it has come from Lucifer's lips. Wind's powers are attributed with multiple scales of gaseous becoming, enacting, and vitality. It is wind and air that link body and cosmos, humans and deities (Adey 2014, 15). The winds' consistency across the centuries and their powerful intermittency emerge and mingle in distinct historical imaginations. 'Yes', Victor concludes, nodding and thoughtful, 'there are many kinds of wind'.

In the town of La Ventosa the wind is a power that cannot be ignored. It comes in gusts and gales. It topples 18-wheel semi-truck trailers and contorts some varieties of trees to only ever leaf and branch in one direction. It makes clothing cling like cellophane, and it will have you momentarily lose your footing; its occasional calm is usually abbreviated. And it is for this reason, in part, that the town of La Ventosa is now completely surrounded by wind parks, in every direction and at the terminus of every road in this little hamlet. For Don Julio wind power has been a boon. Passing through the carport gate that separates his house from the street he remarks on the quality of the wind at that moment. He offers that it is not bad today, just average, as he sets about arranging folding chairs on the concrete slab outside his front windows. Somewhere behind the wall is a young woman, maybe his daughter or daughter-in-law, who is 
preparing plastic cups full of atole, a sugary corn flour drink. Don Julio's home is relatively untroubled by the dust raised by the wind, a dust which saturates seemingly every place in La Ventosa. He lives on a recently paved stretch of road. The deed of pavimentación was carried out by the local government in collaboration with a wind energy company with a park just on the border of town.

Don Julio, a landowner who has leased parcels of his property to the company, appears to be doing quite well. His large two-story home is fresh with paint. He attributes his relative prosperity to his contract with the wind power company and to the monthly rental income from turbine and road placement that it has generated for him. Don Julio epitomizes the developmentalist dreams of wind power in the Isthmus; his growing wealth is imagined to flow in a trickle-down fashion to other less fortunate residents - shopkeepers, laborers, and others without windy land. Don Julio openly shares his story, situating it within a longer history of the town where he has always lived. He is notably philosophical and methodical with his words, and his discourse is more ecological than most. After the atole has been drunk and we have heard a genealogy of renewable energy development in La Ventosa, [End Page 35] Don Julio returns us again to the wind. He wants us to know that the wind itself has made him strong. Like everyone in the Isthmus he explains, living with el Norte - the powerful northern wind that whips across the Isthmus from November to February - has an impact upon a person. 'El Norte picks up rocks, pebbles and sand and it hits you in the face. It gets everywhere. And you have to stand up against it and keep working and keep going in spite of it. It makes you tough and unafraid'. Don Julio is clear about the fact that the turbines on his land and the power of the wind have made him richer. But he also evinces how the wind has crafted aeolian subjects, humans that are abraded, contoured, and affectively shaped by the wind. ${ }^{5}$

Wind power is captured in a conversation, and a series of cosmologies, about how the wind makes people and what people make of the wind. Just as the wind is an oscillation between and among gases, so too is wind defined by its insistence upon a reciprocal exchange between air, humans, and non-human beings and entities. Wind's relationality is important, and indexical, for, as Karen Barad has reminded us, it is relationality that produces entities as 'phenomena', and it is these assemblages, inseparabilities, entanglements, and intra-acting 'agencies' that shift the ways in which we configure things and forces as subjects, or objects, or relata (Barad 2003). The wind is elusive to the visual domain except in places where it touches and moves something else. A pencil drawing of curled lines is a rendering of the wind, as are graphs and charts, but the wind is ultimately only made visible through its impact and influence on other matter, other materials, and other beings. The power of wind confirms a refusal to take separateness as an inherent feature of how the world is (Barad 2007, 136). ${ }^{6}$ And this is, in part, its phenomenological value. As Tim Ingold has described, 'To feel the wind...is to experience [a] commingling' - an existential precondition that isolates both things as objects of touch and the perceiver as a subject who touches. The wind instructs us that we cannot touch unless we can first feel' (Ingold 2007, s29). It is the wind's relationality and, in turn, its phenomenological materializations that work to create aeolian subjects, who live in, from, and through the wind in its various formations and effects. Like the air out of which it is made, wind thrives on interplay and incorporation into, and against, bodies (Choy 2011). Captured by the meters of energy production, but still residing in the domains of myth, legend, and experiential value, 'wind power' contours aeolian political matters and subjectivities. 


\section{ii. Tierra, terreno, land}

Wind (viento, aire) is never separable from land (tierra, terreno) in the Isthmus of Tehuantepec. This is not only because the fierce air always carries earth within it but also because so many local reckonings with force return to the question of who controls the land. Since terrestrial wind power necessitates large tracts of land on which to position turbines, substations, power lines, and access roads, one often finds aeolian politics drawn back to the earth and its masters.

Gravity is felt strongly in the municipio of Juchitán, a binnizá city with a legacy of indigenous political resistance to external power deeply woven into its local knowledge and identity. Juchitecos say they have never really capitulated to foreign powers, not to the federal forces of Mexico City, not to the mestizo Zapotecs of the Oaxacan valley, not to Cortés and his conquistadors, not even to the Aztec empire. It is true that for centuries the Isthmus has existed on the fringes of empire, a place known throughout Mexico for its violent and ungovernable population, cycling between externally imposed projects of political and economic assimilation and autochthonous cultural renaissances. ${ }^{7}$ [End Page 36]

Juchitán has seen intense conflicts over land tenure dating back several decades. The Mexican Constitution of 1917 was revolutionary for its recognition of the pluricultural basis of the nation and for its bestowal of extensive rights on indigenous peoples. Article 27 recognized the right of indigenous peoples to communal ownership and management of ancestral lands via asambleas and guaranteed that these lands could be retaken from colonial hacienda estates if necessary. Haciendismo was not as prevalent in the Isthmus as it was in other regions of Mexico, in part because of resilient indigenous traditions of communal land use and in part because its semi-arid plains were not well-suited to largescale agriculture. Instead, pre-revolutionary Mexico City generally exerted mercantile control over the region through financing small-scale cash crop production.

Even though communal agriculture declined during the course of the twentieth century, gradually being replaced by more individuated forms of farming and relations to land, the asambleas remained strong in many parts of the region. In 1960, around the time the serious land troubles began, $38 \%$ of land in the Isthmus still existed in a communal property regime (bienes comunales), as opposed to $6 \%$ in Mexico more generally. Property rights were not actively sought in a traditional agricultural arrangement in which use, possession, and ownership of land blended together.

The catalyst for an intensified politics of property was the building of the Don Benito Juárez García dam near Jalapa del Marqués northwest of Juchitán along with an irrigation system designed to allow tens of thousands of hectares of Isthmus land to receive adequate water for more intensive and profitable forms of agriculture (Binford 1985). Even before the dam was built, land speculation swept across the Isthmus, encouraging the wealthier smallholder peasants (including among them the descendants of the pre-revolutionary caciques) to accumulate land. Speculation had various effects including consolidating estates, swelling the ranks of landless peasants, and creating sharper class distinctions between landed and landless peasantry. The federal government recognized the potential for serious political unrest and intervened with two federal decrees designed to limit speculation and restore the communal land traditions of Juchitán. But the infelicitous wording of the first decree in 1964 seemed to deny any possibility of smallholder property, which caused the smallholders in turn to organize politically against the state. The second decree in 1966 reinstated smallholder titles but left murky the relationship between possession and ownership of land. A landless peasant movement, Coalición Obrera, 
Campesina, Estudiantil del Istmo (COCEI), began to form in the early 1970s, using land occupation as its chief modality of action, seizing what it viewed as inalienable communal lands back from the landed peasant class.

This contentious history of tierra has shadowed every step of twenty-first-century wind development in the Isthmus. This is particularly clear in the township of La Ventosa, an agencia municipal of Juchitán, and the site of the first commercial wind farm in Mexico, Parques Ecológicos de México (2009). It is true that La Ventosa stands at the western edge of what is regarded to be, technically speaking, the best wind in the region (with average annual wind speed of 9.3 meters/second and top speeds in winter of $30 \mathrm{~m} / \mathrm{s}$ ). But the reason that La Ventosa has become encircled by wind turbines has more to do with the politics of land than the technical quality of wind (Oceransky 2009; Pasqualetti 2011). Since the 1980s, La Ventosa has been the epicenter of militant smallholder politics in the Isthmus. The town's current cacique is Don Porfirio Montero Fuentes, a local Partido Revolucionario Institucional (PRI) and evangelical Christian leader, who rose to power fighting street battles against COCEI in the 1980s. Local historian José Lopez de la Cruz told us: 'It was the 1980s and Porfirio talked a lot about how the reds would come and steal our land from us. And then COCEI did actually try to occupy a large plot of land in La Ventosa, [End Page 37] which belonged to an administrator in Juchitán. I remember Porfirio leading a group of armed men down the street, with guns, sticks, machetes, and they eventually drove the COCEIstas off'. Somewhat ironically, Montero celebrated his victory by taking the majority of the administrator's land for himself and his allies. Montero subsequently became a fierce advocate for private property rights in the Isthmus and used his growing political influence in the governing PRI party to secure something approximating a private property regime at least in the lands surrounding La Ventosa. Montero also developed close relationships with Spanish renewable energy companies like Iberdrola and Acciona Energía, encouraging them to invest in La Ventosa, guaranteeing them that contracts would be upheld by the authority of the state or better yet by him and his political network.

We interviewed Montero around the time the first La Ventosan wind farm was coming on-grid, and he told us he was upset that the lack of government mediation had led to meager returns on the long-term (20+ years) land rents. 'For ten years, I've been telling [the government] that they need to create a committee to regulate what is going on down here and no one has listened to me. Why can't we be paid closer to the price that the government is paying [the companies to produce electricity]. We're the ones producing the energy.... when you look at the generation that is going into their substation, we are only making about $1.5 \%$. Oye eso es sucio' (Yeah, that's just dirty). Montero's thinking was clearly transitioning from a logic of land to a logic of energy in that he wanted rents calculated not by hectare but by megawatt, 100,000 pesos per megawatt, 'this is what we are proposing to them'. ${ }^{8}$ Yet the transition was only halfway in that he still viewed wind as a fixed material resource, much like land, 'it can be low, medium or high but the wind is always blowing'. Thus Montero rejected a variable payments model, insisting on a fixed one, 'the same for all of us'. Bankers in Mexico City later told us that Istmeños have been very creative and persistent in the matter of land rents. 'They've even invented entirely new kinds of rents that don't exist anywhere else', one project financier told us. One of these was derecho de viento, a payment to an individual or community for the wind's passage over a given area of land en route to a turbine, literally a terralogical easement placed on the kinetic force of wind. ${ }^{9}$

In Ixtepec, a municipio to the northwest of Juchitán, a group of comuneros and a NGO, 
Yansa, are working together to develop the first communally owned wind park project in Latin America (Hoffmann 2012). Unlike the commercial model of a 1.5\%-2.5\% payment to rentiers, $50 \%$ of the revenues would be returned to the comuna to be put toward social projects and a retirement fund for aging farmers. Daniel González is one of the leaders of the initiative and a lawyer in town. But he is also the grandson of a rancher and a farmer. Now his grandfather's lands belong to him. 'But along that road where there used to be ranch after ranch, there are now only four remaining and you know how many people still live out there? Just one. Even I don't live there because I have so much going on in town'. In his retirement, he has taken up growing sorghum again, 10 acres, and that taught him how much the infrastructure of irrigation has collapsed over the years, as fewer and fewer farmers worked to maintain it. And other infrastructures were in decline as well, those that linked land and language and ethnicity. Daniel spoke Zapotec in his youth even though almost all his professional life he worked in Spanish. He was teaching his own grandson Zapotec now, taking him out to places around the Isthmus where Zapotec was still the primary spoken language.

The future of the communal wind park project remains uncertain. The national electricity utility, the Comisión Federal de Electricidad (CFE), will not allow themto bid for access to the grid because the comuna and NGO partner do not have sufficient capital in the bank and letters of credit to do so. It is a vicious circle, the NGO founder tells us, "we can easily get sufficient [End Page 38] capital to build the park from socially responsible investors and banks in Europe, but they will only guarantee that credit if we have a contract with CFE for grid access'. The comuna elected to challenge CFE in court. An added twist is that CFE built the largest substation in Latin America on communal Ixtepecan land in order to evacuate all the new electricity from the Isthmus wind farms to the main trunk line toward Mexico City. The comuna claims that CFE never even sought a contract for that use of land, nor formally expropriated it, they simply occupied the land and began building a substation. A squatter grid.

Daniel explained to us, 'So this was a case of exploitation and theft (despojo) on two grounds. First, the illegal occupation of our land by the substation and second by refusing us the right to even compete for access to the substation'. Not only was CFE the target of the complaint, but also the Mexican federal environmental ministry, SEMARNAT, for having granted the CFE the right to cambio del uso del suelo (change of land use) for Ixtepecan land on, it is alleged, a fraudulent basis. The complaint is still winding through the Mexican court system, although Daniel is optimistic that a political solution will be reached to allow the communal park project to proceed.

Elsewhere in Ixtepec, a city of few landed peasants and many landless migrants, optimism regarding 'wind power' is mixed. Like many places where debates about wind power bluster, questions of equity are often at the center of critiques (Wolsink 2007). Raul Mena, one of the many educated yet underemployed young people in town, told us that even if the park happened it would 'only benefit the comuneros anyway' who kept to themselves, maintaining a tradition of communal agriculture that offered little by way of a future to Ixtepec's youth. We asked Raul to whom the Ixtepecan wind belonged and he said, 'To us! To all of us here! It's not like terreno [a plot of land] but it is partly of the tierra [earth]'. We have a similar conceptual slippage in English between 'the earth' and 'land', undoubtedly owing to our own agrarian legacies past. But Raul was making a more specific point - the wind was not like the land of the comuna, it was not something that could belong to just some Ixtepecans. The wind thus hinted at the possibility of a broader redistributive commons, a binding through airborne arid soil, answering the yearning of landless Istmeños to reconnect to 'their' land. 


\section{iii. La red, la luz, grid}

We discovered through our research in Ixtepec that 'wind power' was also very much about the politics of energy infrastructure and specifically about the administration of la red (the grid). It was not solely the political and legal challenges the squatter grid faced in Ixtepec that troubled further development but also the engineering challenges involved in harvesting wind, especially the turbulent wind of the Isthmus.

When we spoke to administrators and engineers at CFE, we discovered widespread ambivalence regarding the merits of wind power because of its lack of constancy. Although there was general agreement that Mexico had wonderful wind resources that ought to be utilized in some way, our interlocutors expressed concern that the nature of the wind did not correspond well to the needs and logic of the grid. 'From the perspective of the administration of energy, there's a type of energy we call "baseload" [energía base]', Francisco Diaz, a department director from CFE explained to us. 'Above all this is thermoelectric energy where you supply it with combustible fuel and it works, just like a motor. It's muy constante [very constant]. Geothermal is that way too. But with all other sources, even hydroelectrics, output will depend on the rains of the previous year. So in a dry year you might not have enough supply to meet demand. It is the same way with las eólicas [the turbines]. You might have a peak supply and an average supply. But those [End Page 39] are just numbers. In reality the supply is constantly fluctuating between highs and lows. And for that reason in most cases of wind energy you need to build extra thermoelectric support installations just to guarantee the supply of energy'. Perversely then, investments in wind power necessitated still further investment in fossil fuel plants, just to guarantee that 'average supply' could be maintained on windless days. Consumers were constantly hungering for energy, 'and they know nothing about how it is generated', one engineer lamented, 'they simply want la luz [light, electricity] when they turn on the switch'.

The principal fear of the electrical engineer was that the thrown switch would yield nothing but further darkness, a negation of their professional expertise and administrative competence (Nye 2010). Journalists in Mexico City told us stories about how, until relatively recently, CFE would sometimes shut power down to entire factories, for hours and without warning, simply in an effort to preserve domestic supply. Many Mexican companies began building their own generating plants as a result, and private electricity generation now accounts for over $30 \%$ of the total national supply. ${ }^{10}$ Even so, we found that the overriding concern of $\mathrm{CFE}$ was that the grid, which remained their property and responsibility, needed to be kept swollen with constante electrical enablement. Intermitencia (intermittency) was a congenital deficiency of 'wind power'. And it often seemed to us that they wished they could be rid of the uncertainty that accompanied it.

To be clear, CFE officials also expressed pride in Mexico's participation in the Kyoto Protocol and understood the environmental disadvantages of the intensification of fossil fuel use. They simply felt, as 'administrators of energy', that intermittency was a plague on their work. Grid managers elsewhere also frequently describe renewable energy as a threat. A study released in May 2014 by the North American Electric Reliability Corporation (NERC) ${ }^{11}$ opens with the statement, 'The North American Bulk Power System is facing a perfect storm of reliability threats that could result in significant changes to the way the power grid is planned and operated. Many of these threats are the result of a combination of traditional baseload generation retirements and the addition of many Variable Energy Resources (VERs) to replace the 
retirements' (NERC 2014). VERs refer to renewable energy sources like solar and wind that create intermittency challenges at the grid level, including the need to keep back-up conventional power sources 'spinning' so that they can [End Page 40] be 'ramped-up' immediately as renewable power drops to bolster 'reliability'. Scenarios like this one the NERC commissioned for California in 2020 visualize these new problematics of engineering reliability. In the scenario depicted in Figure 1, we see abundant daytime solar energy forcing grid operators to scale up and down baseload carbon-fueled electricity generation dramatically over a period of a few hours, necessitating greater real-time attention to supply and demand fluctuations.

January 2020

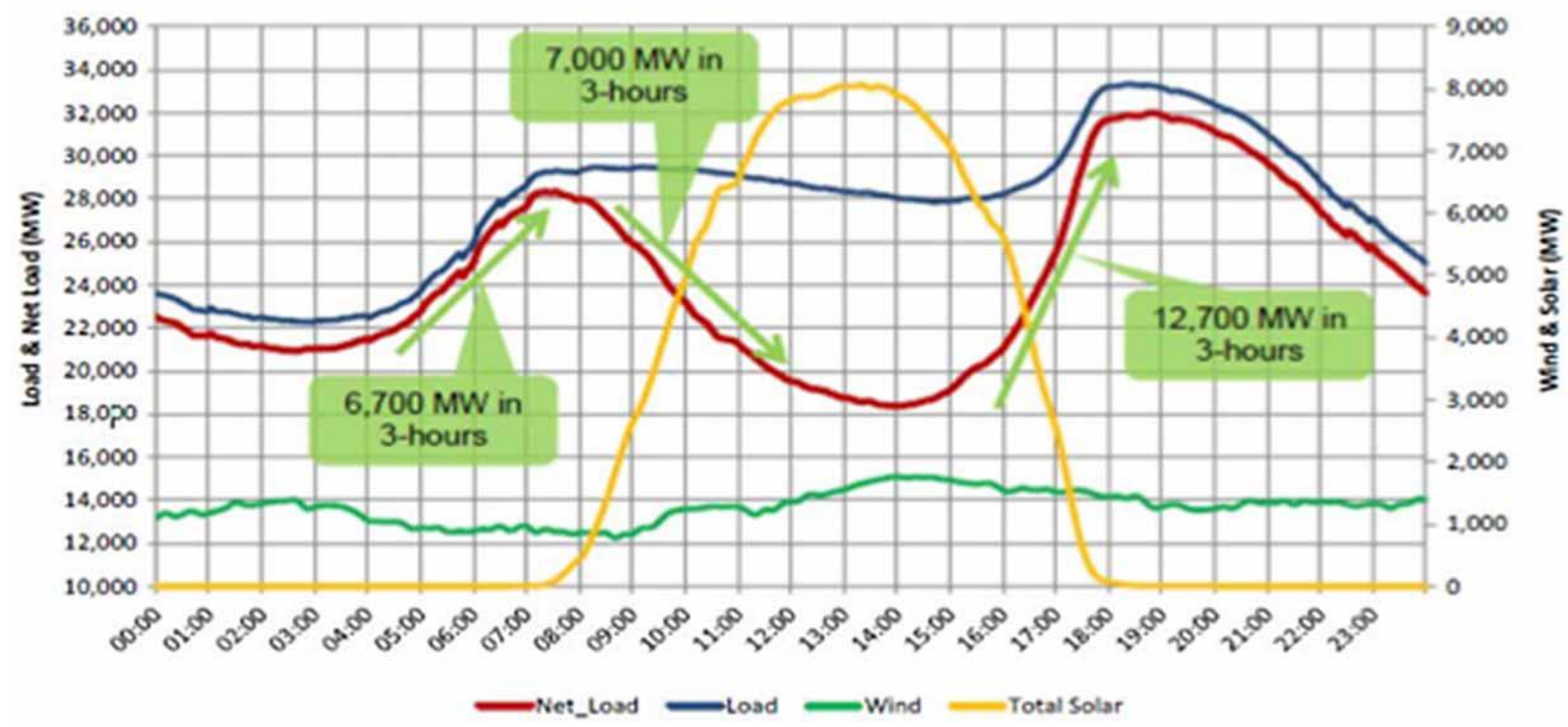

Figure 1. Projected load scenario for California in 2020.

Source: NERC 2014, p14.

Yet, conventional electricity plants cannot be turned on and off like a light switch; they take hours to come up to full generation capacity. Thus, even with abundant renewable energy, managing baseload requires keeping extra MW capacity 'spinning' when it is not needed, a practice grid managers view as necessary but wasteful and expensive. Electrical engineers point to cases like Germany where close to $30 \%$ of electricity is now generated by renewable sources. There the economic fortunes of utility operators are flagging since they are legally required to provide bulk baseload electricity as costs mount and revenues decline, making it an increasingly precarious venture.

And there is more bad news still. A recent study published in the journal Physical Review Letters (Milan, Wächter, and Peinke 2013) found that wind energy was more volatile and turbulent than had been previously calculated. In the researchers' study of a German wind farm, they found that as wind speed changed the power output of the farm could shift by as much as $50 \%$ within two minutes. They also disproved 'the deceptive argument that clustering wind turbines averages out their turbulent fluctuations' (2013, 138701-4). Indeed, the researchers found that regardless of how far apart turbines were spaced, 'wind turbines do not only transfer wind intermittency to the grid, but also increase it...' 
Thus, the squatter substation, Ixtepec Potencia, the largest and most technologically advanced substation in Latin America, is not solely deemed a danger to the Ixtepecan comuneros but also in a certain respect to the grid itself. Absent some capacity for massive energy storagewhich continues to be deemed technologically and economically unfeasible at present-Ixtepec Potencia is a net turbulence importer to the Mexican national grid. To help combat this threat, CFE purchased a state-of-the-art Static Var Compensation (SVC) system from the Swiss firm $\mathrm{ABB}$ to mitigate power oscillations on the high-voltage line from the Isthmus to the main trunk line. As an ABB spokesperson explained to us, 'Even before wind power, grid operators have faced the challenge to balance the power produced and the power consumed, due to the fact that energy is still today technically expensive to store. So all power produced has to be consumed. Before this intermittent generation was inserted into the grid, the challenge was mostly due to the variations in the load side and disturbances caused by long transmission lines. Nowadays, with these new forms of cleaner energy, the challenge is greater as disturbances ${ }^{12}$ come also from the generation side which before was more easily controlled'.

These are the energopolitics (Boyer 2014) of renewable energy, the front lines of transformational struggle hidden within the infrastructural ubiquity and opacity of la red. Hidden too is the growth imperative of the grid, needing massive demand to meet massive supply since 'all power produced has to be consumed'. Istmeño critics of wind power recognize this paradox. One activist told us: 'All this supposed clean energy is going to power more Walmarts and cement factories, and those are the true problem'. And, yet, Mexico's Green Revolution continues to advance.

\section{iv. Verde, green}

The Kyoto Protocol never demanded that the country of Mexico reduce its emissions. And yet President Felipe Calderón (2006-2012) inaugurated legislation ${ }^{13}$ that made Mexico one [End Page 41] of the few developing countries in the world to enshrine long-term, comprehensive climate targets into law. In June 2009, the federal government formally committed to a detailed plan for green house gas reductions, the Programa Especial para Cambio Climático, targeting a $30 \%$ drop in emissions by 2020 (and 50\% by 2050). The Renewable Energy and Energetic Transition law (2008) requires that $35 \%$ of electricity come from non-fossil fuels by 2024 , growing to $40 \%$ in 2030 and 50\% in 2050 . Calderón's decision to pursue this legislation was compelled by his long-standing interest in environmental protection which, he explained to us, stemmed from when he was a teenager and first learned about ice cap melts, deforestation, acid rain, and the ecological limits of growth. Calderón sees his country as deeply implicated in the fossil fuel complex, with up to $43 \%$ of the federal government budget dependent on the profits of Petróleos Mexicanos (PEMEX), the national oil company. Vulnerable to the fiscal turbulence of oil as a commodity and equally susceptible to the contingencies of a carbonized climate, he explained that 'sooner or later, Mexico will need to face the problems related with climate change, because while [Mexico is an oil producer] it is also one of the countries that will suffer the most - the consequences - and it is suffering already'. When it comes to oil, he went on, 'you can depend less, you know, every day if you decide to'.

'Deciding to' generate sustainable forms of energy is also a decision to intervene in the ethics of climatological care. However, while wind power operates to inhibit carbon combustion, it is equally an investment in the suspect growth imperative of modernity, ensuring that power 
consumption endures and that energy production, now greened, continues to generate profits. Throughout the Isthmus of Tehuantepec where parks have bloomed in every direction, the advent of renewables and carbon mitigation targets have raised questions about how sustainable energy projects may disenfranchise local populations and limit local autonomy to determine how land, air, and water are to be used and managed. Wind power thus becomes a site of political contestation and scalar debates regarding the good of the planet versus the good of the people. In this fraught struggle over interests, global and localized, an ethical tension is pulled more taut, and wind power's supporters leverage green assurances and a promissory future. Wind power is an energetic source to be sure, but it is also a device through which corporate and state interests craft their ecological profile and proclaim moral authority in the practice of climatological care.

Four beautiful women outfitted in the colorful splendor of binnizá traditional dress make for a telegenic scene poised against a backdrop of enormous turbine columns, white and new and gleaming. Almost everyone else here is not a woman. There are government officials, municipal leaders, engineers, and electric company representatives. The media are present in unusual abundance, waiting for the president of the republic and the governor of the state to helicopter in. The inauguration of this wind park near Santo Domingo Ingenio will be Calderón's last of many wind park ribbon-cutting ceremonies. When he was Secretary of Energy, Calderón advanced the cause of wind energy across Mexico. Now, as his presidential term nears its end, the installed capacity of Mexican wind accounts for a huge percentage of the country's clean development mechanisms. Calderón's speech today is not triumphant, nor is it a swan song. Instead it pivots between hope and precarity. He begins with droughts, the most severe ever seen in Mexico and to the north in Texas. 'This is climate change', he says to his audience of several hundred seated in front of him. 'Carbon dioxide is like a sweater surrounding the earth', heating the ocean's waters and making for both more and less rain that is, overall, differently distributed. 'However', he goes on, 'we cannot stop using electricity or building factories. Instead we need to make electricity with less smoke. We need to reduce emissions'. And here, in the heart of the Isthmus is where much of this is already occurring. [End Page 42] The president calls attention to the engineering careers that wind power has brought to Oaxaca, and to the jobs in the supermarkets, now more plentiful because of the 'economic spillover' of wind power. But Calderón's ethical intervention and wind power's role in it represent more than local jobs in Isthmus towns. 'Mexico', he says, 'is an important part of all humanity, the twelfth most populated country in the world' and thus and therefore, a place that can make a climatological difference, here and now.

The Mexican Ministry of Energy has lauded the growth of renewable energy projects. From the perspective of SENER, wind power, specifically, has many vectors of potential, locally, nationally, and globally. The winds of Oaxaca are, according to SENER:

an opportunity to reduce emissions without compromising national economic development; an opportunity to contribute to climate change mitigation; an opportunity to attract investment to Mexico; an opportunity to develop local capabilities; an opportunity for technological development; an opportunity to increase the nation's global competitiveness. (SENER 2007, 32-3)

One of the reasons that 'opportunity' so fluidly emerges in state discourses is that in addition to being the site of some of the best wind in the world, Oaxaca is also one of the poorest states in the country, a place where economic development is often prioritized in government programs and politicians' ambitions. The director of Sustainable Energy for the State of Oaxaca relayed this in unambiguous terms. 'If it weren't for the wind, there would be no development [in the 
Isthmus]'. For many state officials their conviction to promote economic development through sustainable means - such as wind power - is, in part, an ethical calling to bring further degrees of prosperity to the region. The future of the Isthmus is, in this way, married with the development plans of private capital in a tidy moral tale that is often described as 'win-win-win'. Opportunity is articulated across all dimensions of social life and economic health - from investment metrics, to local capability enhancement, to global climate change mitigation. Federal governmental offices, such as SENER, designate a series of environmental and economic futures as the proper way forward for the nation; in turn, they also burnish their own green reputational value. Wind power is positioned as a remedial method of ecological care and as a generator of economic value and technological potential. But wind power is also the material instantiation of an ethical exercise intended, at least nominally, to benefit the 'greater good', of local populations and the Mexican nation and, ultimately, in service to the planetary bios.

The Mareña Renovables wind park is a case in point. Had it been constructed it would have been the largest single-phase wind power project in all of Latin America. It was designed for a total installed capacity of $396 \mathrm{MW}$ of gross power with 102 turbines to be positioned across the Barra de Santa Teresa, and another 30 in the town of Santa Maria del Mar. The Mareña park would have prevented 879,000 tons of greenhouse gas emissions, and it would have represented a new scale and dimensionality to wind power in the Isthmus of Tehuantepec, providing the equivalent of half a million homes' worth of renewable electricity. The proposal for the Mareña project had all of the signature elements of success in a time of neoliberal development projects and attempts to staunch climatological harm. It was bank-rolled by international development banks and touted as a boon for local communities by government representatives - from officials in Mexico City and the state capital, to provincial authorities in the Isthmus. All of its environmental credentials appeared indisputable: from infinitesimal attention to local ecosystem protections (preserving mangroves, jack-rabbits, sea turtles) to the colossal demands of safeguarding the climate (averting gases, particulate matter, carbon combustions). ${ }^{14}$ The Mareña consortium carefully deployed its ecological authority as it sought to maintain equilibrium across [End Page 43] different scales of environmental and human health. Local protestors, however, were unconvinced. They believed that the park would cause irreparable environmental harm and diminish fishermen's catch, and, perhaps worse still, it would represent yet another mode of colonial extraction in what the opposition called la nueva conquista (the new conquest) of green neoliberalism. It was their blockades of roads and passages and their national and international media attention that delayed the Mareña project into oblivion, until it ultimately became the wind-park-that-never-was.

In the case of Mareña, wind power was positively charged with a potential to foment local economic growth and remediate global ecological conditions. Its negative polarities were equally dense constellations based on centuries of suspicion and contemporary conditions of deprivations and deceits. The project was scaffolded by the eco-authoritiative positions of environmental impact reports and ethical claims to protect the global biosphere, but ultimately derailed by demands for local sovereignty and stewardship (Howe 2014). Aeolian politics represent a constellation of forces and materials that involve corporate sustainability profiles, government projects and the performance of climatological care, but it is often in the "devil's wind" that questions of environment and authority raise turbulent questions about ecological futures. 


\section{v. On the mission of critical theory in the Anthropocene}

In his turn to face the Anthropocene, Bruno Latour has wondered what has taken the wind out of critique. Citing his own role in attending to the constructedness of scientific facts, he laments the ink given to climate change denialists whose tactics seem eerily parallel. He worries about deconstruction abetting destruction (Latour 2004b, 225) and hopes to refocus our attention not on matters of fact but rather on 'matters of concern'.

Wind power is one such a matter of 'concern'. It is by turns object, operator and index, ever a venti/fact/ish over which corporate executives, politicians, engineers, landowners, activists, neighbors and anthropologists can all exert their varying degrees of epistemic and moral authority. Wind power is the nexus for a series of competing, and also often compelling, ethical projects, forms of expertise, and political claims. Wind power offers a medium in which propositions of value circulate and, ultimately, manifest in an abundance of materio-political forms - among them, turbines, substations, voltage regulators, carbon credits, rents and profits. Materio-political forms indeed make circulations visible (Gaonkar and Povinelli 2003) and they affect the constitution of political actors and their engagements (Barry 2001; Bennett 2010; Mitchell 2011; Braun and Whatmore 2010).

But the urgency of the Anthropocene means that we also need to practice deconstructing and reconstructing some of our more comfortable objects of salvation. For as our analysis of aeolian politics shows, 'wind power' is not one but many 'things', differing ensembles of force, matter and desire. Wind power has no summary form; it is a matter of pressures, flows and frictions, air moving around and through efforts by authoritative discourse and knowledge to orchestrate it as a simple 'object' of analysis, intervention and action. Still, we do not doubt that wind power has objective political efficacy any more than we doubt that the Istmeño wind blows the roofs off houses and flips tractor-trailers, abandoning them like beached whales on asphalt shores. But, to stay true to that wind, it blows in many directions and intensities - it is the cruel wind of the devil and also the soft breeze of redemption. What we are trying to say is that some constellations of aeolian politics may be capable of blowing us back toward the Holocene; others will not.

One final comment: Our exploration of aeolian politics absorbs inspiration from political materialism, and from the broader anti-anthropocentric turn in the human sciences. [End Page 44] But just as the Istmeño wind agitates, we do not want that turn to be too comfortable in its revelations. Yes, materials, forces and infrastructures matter to wind power, but so do signs, discourse, phenomenology, policy, human agency. If we pass gently into the posthuman without demanding accountability for the modern species being that continues to warm the earth and extinguish its forms of life, the task of critique will remain incomplete. We thus urge political materialism and more traditionally anthropocentric political analysis to collaboratively engage one another. The point, after all, is not who owns and deploys the better concepts. The point is to develop a critical analysis adequate to the epistemic and ethical challenges of life on a damaged planet. 


\section{Acknowledgements}

Our work was made possible only because of the generosity of time, energy, and commentary that we found among our friends and interlocutors in the Isthmus of Tehuantepec, Oaxaca City, and Mexico City. We cannot name each of you here, but we have endeavored to incorporate the important messages that you shared with us. Finally, we hope that our research will ultimately lead to better energy transitions in the region, and in the world, in the future. For their careful consideration and critiques, we also appreciate Hannah Knox and our anonymous reviewers at Distinktion.

\section{Disclosure statement}

No potential conflict of interest was reported by the author.

\section{Funding}

This research was funded by the National Science Foundation, Cultural Anthropology [grant \#1127246].

\section{Notes}

1. This article is based on a collaborative research project by the authors. Initial research in 2009 and 2011 was followed by extended fieldwork from May 2012 until August 2013 which generated hundreds of interviews with those involved in, or implicated in, the development of wind power in the Isthmus of Tehuantepec including local residents, private landowners, collective landholders, wind park developers and corporate representatives, journalists, activists, investment and development bankers, as well as local, state, and federal government officials in Oaxaca City, Mexico City, and several municipalities in the Isthmus.

2. We distinguish the concept of 'aeolian politics' from the general term 'wind power' for several reasons. 'Aeolian' draws its etymology from Aeolis, the Greek god of wind, but we also derive aeolian from the emic categories voiced by our interlocutors. Los Eólicos is the Spanish term commonly used in Oaxaca to designate wind park developments, and wind-generated energy is dubbed energía eólica. Equally ubiquitous across the Isthmus of Tehuantepec is resistance to the proliferation of wind parks, known locally as the antieolico struggle. Finally, aeolian processes are defined as the effect of wind upon geological and weather phenomena; most specifically aeolian processes signal how the wind contours or shapes planetary surfaces. Our 'unwinding' of wind power draws from each of these dimensions, with an attention to the contemporary reshaping of our planet's surface in the Anthropocene.

3. Wind machines (to test aerodynamics for example) or fans (for cooling) are instances of human-generated wind, but their fundamental property continues to be (gaseous) movement and interaction. Unlike solid (minerals, coal), liquid (water), or viscous (oil) 
resources, wind only exists in motion; it is generative solely through movement. It is contra-static.

4. These stanzas are excerpted from Terán's poem, published in English in Poetry Magazine (April 2009).

5. Here we are designating a subjective status of a man worn and having won in particular ways, through the wind. Don Julio did not describe himself as an 'aeolian subject', but he was clear that his life had in fact been deeply contoured by wind's effects and powers.

6. Barad calls for an 'agential realist ontology' wherein 'phenomena are the ontological inseparability/entanglement of intra-acting "agencies"” $(2007,139)$.

7. We do not wish to understate the national and imperial (Spanish, Mexican, United States) ambitions for the Isthmus nor their legacies, ranging from interoceanic canal-building plans of the early twentieth century to the more elaborate infrastructures of Proyecto Mesoamerica today. Our point is simply that these ambitions have been frequently contested and sometimes thwarted by local resistance. The Isthmus has long troubled the realization of imperial aspiration.

8. Given the figures Iberdrola estimated to us in December 2011, that they were paying roughly 7,000,000 pesos a year for $80 \mathrm{MW}$, Montero's suggestion would have amounted to a $12.5 \%$ increase in payments.

9. The history behind derecho de viento is a matter of some speculation and dispute in the Isthmus. But local historians and journalists suggested to us that it was a practice designed to help spread rents more evenly especially when land was held in an ejidal property regime. Thus, for example, even if an ejidatario possessing the land upon which a wind turbine would be built would receive a lucrative rent contract, a neighboring plot of land would still receive some benefit via derecho de viento. Even though the Salinasera reform of the ejido system encouraged ejidatarios to consider their plots as private property, derecho de viento suggests a certain enduring communitarianism among collective landholders.

10. For this reason, the majority of wind park projects in Mexico are organized in a publicprivate partnership scheme known as autoabastecimiento in which a wind power developer signs a long-term power purchase agreement with an industrial partner (examples include Walmart, CEMEX, FEMSA-Heineken) mediated by CFE, which, as a matter of Mexican law, is the only entity actually authorized to purchase and sell gridbased electricity in the country.

11. NERC is a non-profit organization established by the electrical utility industry in 1968 in response to the Northeast Blackout of 1965 to set standards for power system operation and to coordinate planning and operation of the 'bulk power system' of the United States, Canada, and part of Baja, Mexico.

12. These disturbances include rapid voltage fluctuations, overloads and underloads that can be damaging to equipment designed for stable current. Electricity infrastructure in the Isthmus, it must be added, was plagued by problems long before wind power arrived. Some Istmeño communities experience routinely intermittent electrical service, a fact which is routinely blamed on CFE for their greed and incompetence.

13. In May 2007, President Felipe Calderón announced the National Climate Change Strategy, instituting climate change mitigation as a central part of national development policy. In 2012, before leaving office, Calderón signed the General Climate Change Law that formalized targets set in previous legislation, inaugurated the National Institute of 
Ecology and Climate Change, and coordinated federal offices to develop holistic mitigation and accommodation planning.

14. The Mareña project then recapitulates Latour's diagnosis of political ecology (2004a): it ideologically claims to defend nature for nature's sake (in the register of a biocentric logic as opposed to an anthropocentric one) but nonetheless continues to assign stewardship to humans and is predicated on the well-being, comforts, pleasures, and good-feeling conscious of a few (select) humans.

\section{Notes on contributors}

Cymene Howe is Associate Professor of Anthropology and a core faculty member in the Center for Energy and Environmental Research in the Human Sciences and the Center for Women, Gender and Sexuality at Rice University. She also co-edits the journal Cultural Anthropology (2015-2018) as a member of the editorial collective. Her earlier research-focused on sexuality, rights and subjectivity — has been published in several journals, crossing disciplinary boundaries, and her book Intimate Activism: The Struggle for Sexual Rights in Postrevolutionary Nicaragua was published by Duke University Press in 2013. Her research priorities are now centered on ecologics, energy, and the politics and materiality of climate change. Her forthcoming book with Cornell University Press, Ecologics takes an experimental scholarly form, a duograph, written in parallel with Dominic Boyer. The multimedia volume follows renewable energy transitions in Oaxaca, Mexico and draws upon the overlapping conversations between feminist and queer theory, new materialisms, multispecies ethnography, ontologies and imaginaries of the future in the Anthropocene.

Dominic Boyer is Professor of Anthropology at Rice University and Founding Director of the Center for Energy and Environmental Research in the Human Sciences (CENHS, culturesofenergy.org), the first research center in the world designed specifically to promote research on the energy/environment nexus in the arts, humanities and social sciences. He is part of the editorial collective of the journal Cultural Anthropology (2015-2018) and also edits Expertise: Cultures and Technologies of Knowledge, a book series for Cornell University Press. His most recent book is The Life Informatic: Newsmaking in the Digital Era (Cornell University Press, 2013). With James Faubion and George Marcus, he has recently edited, Theory can be more than it used to be (forthcoming, Cornell University Press) and with Imre Szeman is preparing Energy Humanities: A Reader for Johns Hopkins University Press. His next book project is a collaborative multimedia duograph with Cymene Howe, which will explore the energopolitical complexities of wind power development in Southern Mexico.

\section{References}

Adey, P. 2014. Air. London: Reaktion Books.

Barad, K. 2003. Posthumanist performativity: Toward an understanding of how matter comes to matter. Signs: Journal of Women in Culture and Society 28, no. 3: 801-31.

Barad, K. 2007. Meeting the universe halfway: Quantum physics and the entanglement of matter. 
Durham, NC: Duke University Press.

Barry, A. 2001. Political machines: Governing a technological society. London: Continuum.

Bennett, J. 2010. Vibrant matter: A political ecology of things. Durham, NC: Duke University Press.

Binford, L. 1985. Political conflict and land tenure in the Mexican Isthmus of Tehuantepec. Journal of Latin American Studies 17, no. 1:179-200.

Bogost, I. 2012. Alien phenomenology, or what it's like to be a thing. Minneapolis: University of Minnesota Press.

Boyer, D. 2014. Energopower: An introduction. Anthropological Quarterly 87, no. 2: 309-34.

Braun, B., and S.J. Whatmore, eds. 2010. Political matter: Technoscience, democracy and public life. Minneapolis, MN: University of Minnesota Press.

Choy, T. 2011. Ecologies of comparison: An ethnography of endangerment in Hong Kong. Durham, NC: Duke University Press.

Choy, T., and J. Zee. 2015. Condition: Suspension. Cultural Anthropology 30, no. 2: 210-223, Special Section, 'Life above Earth'. Available at: http://www.culanth.org/articles/772conditionsuspension (open access). Accessed May 25, 2015

Descola, P. 2013a. The ecology of others. Chicago: Prickly Paradigm Press.

Descola, P. 2013b. Beyond nature and culture. Chicago: University of Chicago Press.

Gaonkar, D.P., and E.A. Povinelli. 2003. Technologies of public forms: Circulation, transfiguration, recognition. Public Culture 15, no. 3: 385-97.

Harman, G. 2010. Toward speculative realism: Essays and lectures. New York: Zero Books.

Hoffmann, J. 2012. The social power of wind: The role of participation and social entrepreneurship in overcoming barriers for community wind farm development. Lessons from the Ixtepec Community Wind Farm Project in Mexico. MAThesis. Lund University Centre for Sustainability Studies.

Howe, C. 2014. Anthropocenic ecoauthority: The winds of Oaxaca. Anthropological Quarterly 87, no. 2: 381-404.

Howe, C. 2015. Life above earth: An introduction. Cultural Anthropology 30, no. 2: Special Section, 'Life above Earth'.

Ingold, T. 2007. Earth, sky, wind and weather. Journal of the Royal Anthropological Institute 13, April (issue supplement): s19-38.

Jasanoff, S. 2010. A new climate for society. Theory, Culture and Society 27, nos. 2-3: 233-253.

Latour, B. 2004a. Politics of nature: How to bring the sciences into democracy. Cambridge, MA: Harvard University Press.

Latour, B. 2004b. Why has critique run out of steam? From matters of fact to matters of concern. Critical Inquiry 30, Winter: 225-48.

Latour, B. 2005. Reassembling the social: An introduction to actor-network-theory. Oxford: Oxford University Press.

Massumi, B. 2009. National enterprise emergency. Theory, Culture and Society 26, no. 6: 15385.

Milan, P., M. Wächter, and J. Peinke. 2013. Turbulent character of wind energy. Physical Review Letters 110, 29 March: 138701.

Mitchell, T. 2011. Carbon democracy: Political power in the age of oil. London: Verso.

Morton, T. 2013a. Realist magic: Objects, ontology, causality. Ann Arbor, MI: MP Publishing, Michigan University Library.

Morton, T. 2013b. Hyperobjects: Philosophy and ecology after the end of the world. 
Minneapolis, MN: University of Minnesota Press.

NERC. 2014. Essential reliability services: A tutorial for maintaining bulk power system reliability and adapting to a changing resource mix. www.nerc.com.

Nye, D.E. 2010. When the lights went out: A history of blackouts in America. Cambridge, MA: MIT Press.

Oceransky, S. 2009. Wind conflicts in the Isthmus of Tehuantepec: The role of ownership and decision-making models in indigenous resistance to wind projects in Southern Mexico. The Commoner 13, winter: 203-22.

Pasqualetti, M.J. 2011. Social barriers to renewable energy landscapes. The Geographical Review 101, no. 2: 201-23.

Scheer, H. 2004. The solar economy: Renewable energy for a sustainable global future. London: Earthscan.

SENER. 2007. Energía eólica y la política energética mexicana. Ing. Alma Santa Rita Feregrino Subdirectora de Energía y Medio Ambiente, SENER. Monterrey, México Octubre 2007.

Stengers, I. 2010. Including nonhumans in political theory: Opening Pandora's box? In Political matter: Technoscience, democracy, and public life, ed. B. Braun and S.J. Whatmore, 335. Minneapolis: University of Minnesota Press.

Stewart, K. 2011. Atmospheric attunements. Environment and Planning D: Society and Space 29: 445-53.

Terán, V. 2009. “The North Wind Whips,” Poetry Magazine (April). Available at: http://www. poetryfoundation.org/poetrymagazine/poem/185327. Accessed 23 May 2015.

Wolsink, M. 2007. Wind power implementation: The nature of public attitudes: Equity and fairness instead of 'back yard' motives. Renewable and Sustainable Energy Reviews 11: 1188207. 